\title{
CYTOLOGICAL STUDIES IN THE GRAMINEAE
}

\author{
D. N. SINGH and M. B. E. GODWARD
}

Botany Department, Queen Mary College, London

Received 5.iv.60

There are still many tropical and warm temperate grasses, particularly those of Asia, Australia and Africa whose nuclear cytology has not been fully investigated and whose taxonomy is still difficult or has been subject to recent investigation. A cytological study of some of these has been begun. The investigation of special problems which have been suggested by $\mathrm{Mr} \mathrm{W}$. D. Clayton and Mr J. K. O'Byrne of the Herbarium, Kew, and Mr W. H. Foster, Samaru, Nigeria, will be published elsewhere.

Root-tips of seedlings and young anthers have been used for chromosome counts in 53 species belonging to 25 genera of the family Graminee (table I). For two genera, Calyptochloa of Queensland, Australia and Tetrapogon of Kenya, and 29 species the counts are new. Others differ from those found by previous workers (see Darlington and Wylie, I955).

\section{NOTES ON TABLE}

\section{ANDROPOGON: Species Hybrids}

Material of Andropogon gayanus Kunth, showing morphological differences has been collected by $\mathrm{Mr} \mathrm{W}$. H. Foster from different parts of Nigeria. Morphological differences seem to be associated with polyploidy and aneuploidy. The distribution of these forms found by $\mathrm{Mr}$ Foster in Nigeria appears to be such that the diploid A. gayanus Kunth $(2 n=20)$ are in the north of the country, and diploid A. tectorum Schumach and Thonn in the south. The tetraploids $(2 n=40)$ and the aneuploids $(2 n=35$ to 43$)$ are between them. These latter are presumably hybrids. These plants are being grown on for further studies and further collections are being made in Nigeria. The previously recorded chromosome number for the variety (A. gayanus var. squamulatus (Hochst.) Stapf) is $2 n=40$ (Moffett and Hurcombe, 1949).

\section{PASPALUM: Somatic Instability}

Material of Paspalum dilatatum Poir. has been studied. Part of this was sent from Nigeria by Mr W. H. Foster, and part from Toulouse, France. The two lots of material showed similar cytological aberrations. In one and the same root-tip, chromosome numbers ranging from 40 to 63 were found. In meiosis, 6-1o univalents appeared at metaphase I and lagged at anaphase I. In dyads, tetrads and pollen 
TABLE I

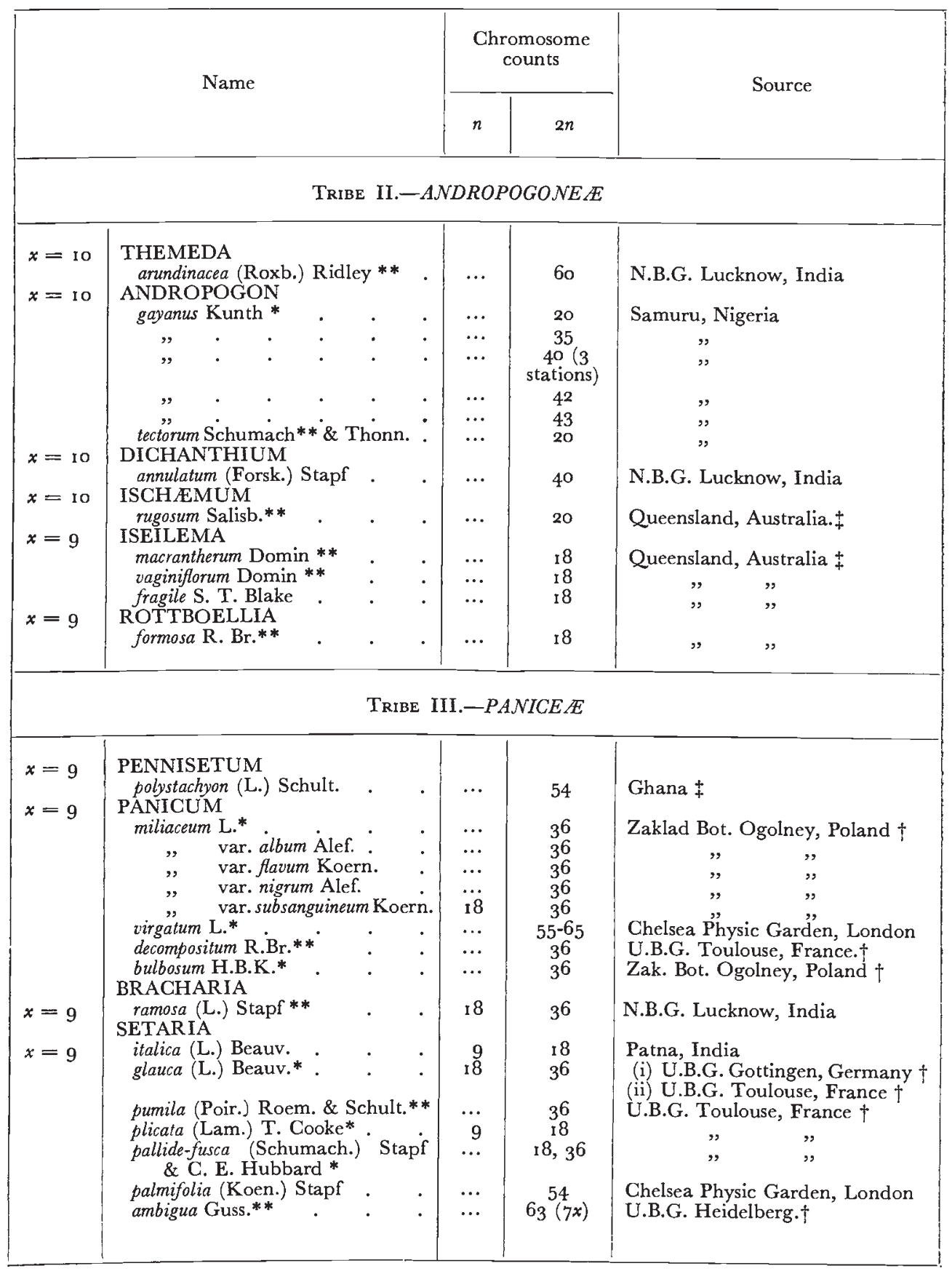




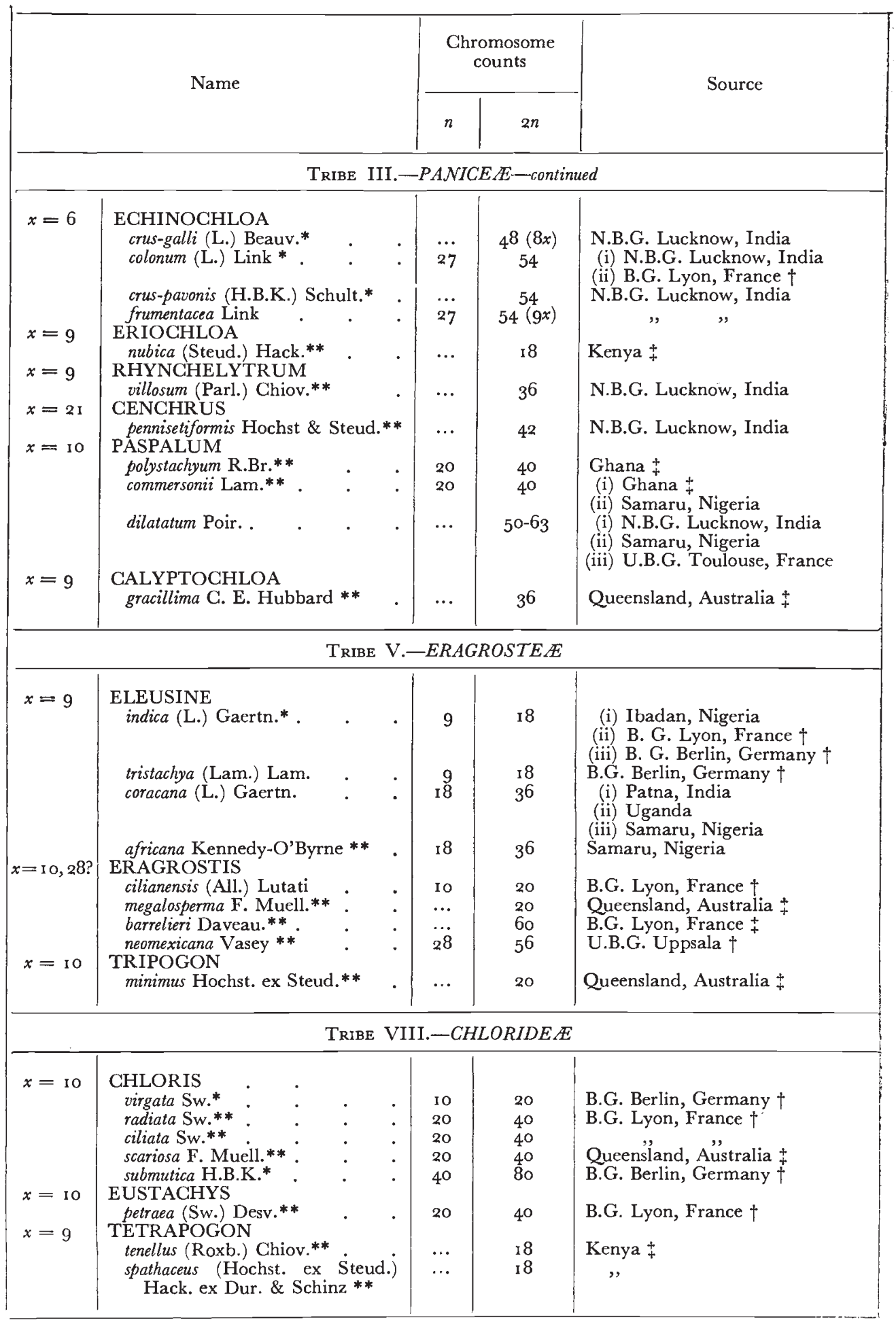




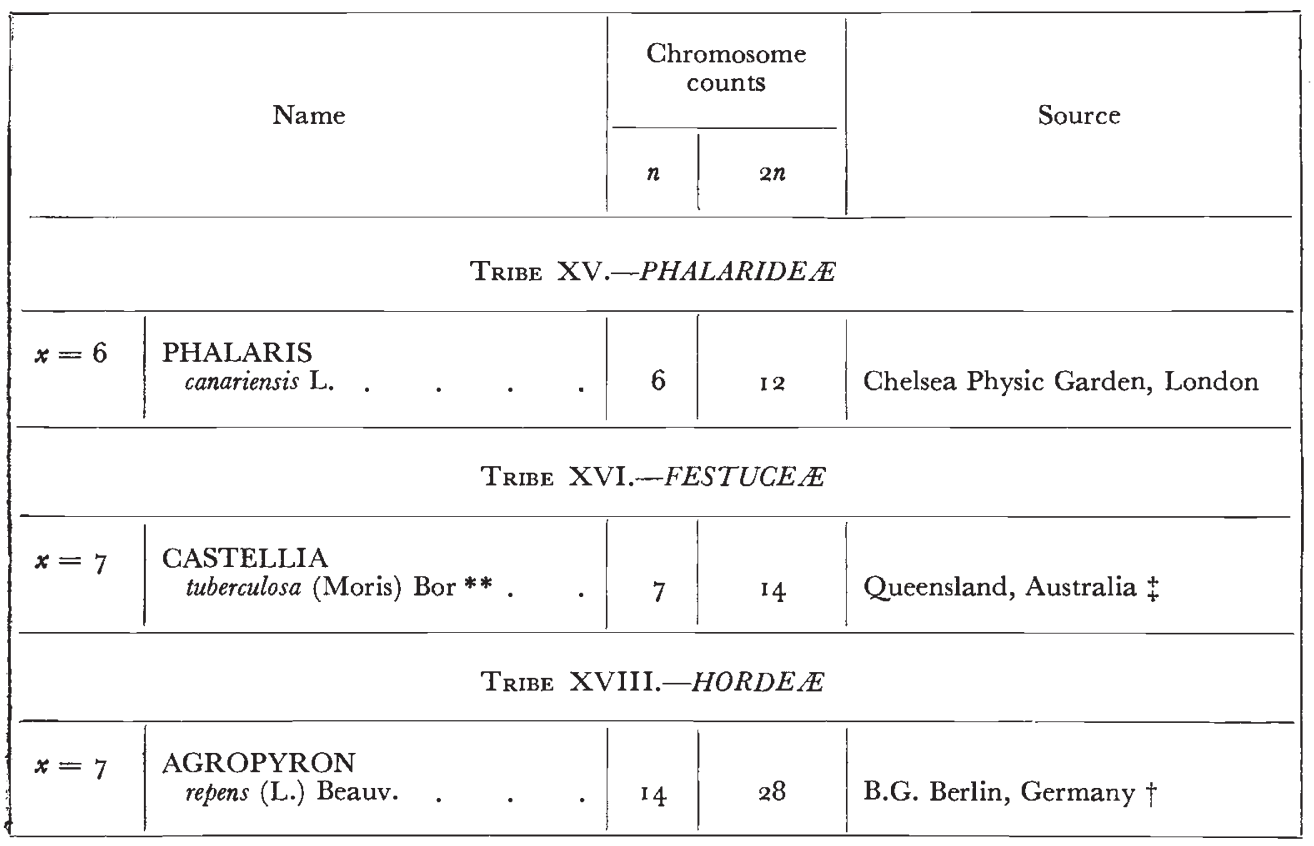

* Difference from the count previously recorded (see Chromosome Atlas for full references).

** Indicates new counts.

+ Seeds received through Chelsea Physic Garden, London.

$\ddagger$ Seeds received through The Royal Botanic Gardens, Kew, U.K.

Abbreviations used :-

B.G.-Botanic Garden

N.B.G.-National Botanic Garden

U.B.G.-University Botanic Garden

grains I to 4 chromosomes are seen outside the nuclei. The development of 2 embryos in the embryo sac of this species contributes evidence of apomixis. Seedlings of the same species from India have $2 n=50$.

Previous Reports: In mitosis, Brown (1948) found $2 n=40$, Krishnaswamy (I940) $2 n=50$, Smith (I948) $2 n=4$ o, Hayman (I956) $2 n=5^{\circ}$.

In meiosis, Hayman found regularly io univalents and Smith 20 univalents. Both these authors found regular or nearly regular behaviour of the univalents and speak of 60 per cent. of " presumably functional " pollen grains. This more or less regular behaviour was not traceable in the present study in either stock.

Acknoweledgments.-The authors' thanks are due to the following for supply of seeds : The Director, The Royal Botanic Gardens, Kew ; The Curator, Chelsea Physic Garden, London; The Director, The National Botanic Gardens, Lucknow, India ; Dr J. P. Sinha, Head of Botany Dept., Science College, Patna, India ; Mr W. H. Foster, Regional Research Station, Samaru, Nigeria ; and to Dr N. L. Bor, Mr C. E. Hubbard, Mr W. D. Clayton and Mr J. Kennedy-O'Byrne for invaluable help in identifying herbarium material grown from the seeds supplied. 


\section{REFERENCES}

BRown, w. v. 1948. A cytological study in the Gramineæ. Amer. Four. Bot., 35, 382-395.

Darlington, C. D., AND wylie, A. P. 1955. Chromosome Atlas of Flowering Plants. Allen and Unwin, London.

hayman, D. L. 1956. Cytological evidence for apomixis in Australian Paspalum dilatatum. Austral. Inst. Agri. Sci. Jour., 22, 292-293.

KRISHNASWAMY, N. I940. Untersuchungen zur cytologie und systematik der Gramineen. Beih. bot. Zbl., 6o, I-56.

moffett, A. A., And hURCOMbe, R. 1949. Chromosome numbers of South African grasses. Heredity, 3, 369-373.

smith, в. w. 1948. Heredity and apomixis in the perennial grass, Paspalum dilatatum. Genetics, 33, 628 . 